\section{INFLUENCE OF QUICK MASSAGE AND PILATES ON THE OCCUPATIONAL HEALTH OF WORKERS OF A PRIVATE VALUE SECURITIES NETWORK AGENCY: A CLINICAL, CONTROLLED, RANDOMIZED AND BLIND STUDY}

\author{
Renata Michele Ângelo de Oliveira' ${ }^{1}$, Mônica Beatriz Ferreira² \\ Gabriela Xavier Santos ${ }^{3}$, Danillo Barbosa ${ }^{4}$, Ivo I. Kerppers ${ }^{4}$
}

Clin Biomed Res. 2018;38(3):206-212

1 Centro Universitário de Itajubá (Fepi). Itajubá, MG, Brasil.

2 Centro Universitário do Sul de Minas Gerais (Unis). Varginha, MG, Brasil.

3 Universidade Federal de Alfenas (Unifal). Alfenas, MG, Brasil.

4 Universidade Estadual do Centro-Oeste do Paraná (Unicentro). Guarapuava, PR, Brasil.

Corresponding author:

Danillo Barbosa

danillo.barbosa@hotmail.com

Universidade Estadual do Centro-Oeste

do Paraná (Unicentro)

Rua Padre Salvador, 875 .

85015-430, Guarapuava, PR, Brasil.

\section{ABSTRACT}

Introduction: This study aims to analyze the influence of quick massage and pilatespilates on bank employees. The project was sent to the Research Ethics Committee and obtained a favorable opinion (1,045,371 / 2015).

Methods: It is a clinical, controlled, randomized, and blind study. The study had had initially involved 70 employeesparticipants, but only 50 were included. They were divided into 3 groups: quick massage group $(n=20)$, ppilates group $(n=20)$ and control group $(n=10)$. They were evaluated with experimental times of 3,6 and 9 months and the protocol was applied 3 times per week.

Results: The results of the present study were presented in standard deviation and mean of all groups, then a one-way analysis of the variance was performed, obtaining a value of $\mathrm{P}<0.0198$, being considered significant. However, it is noted that when presenting the detailed data of each group (mean and standard deviation) it is observed that the group which received the quick massage had a small advantage.: (6 months) $4.03 \pm 0.82$, (12 months) $3.43 \pm 1.15$ and pilatespilates group ( 3 months) $6.21 \pm 1.98016$, (6 months) $4.26 \pm 0.57873$ (9 months) $4.14 \pm 0.63$.

Conclusions: The quick massage techniques and the pilatespilates protocol have shown great potential in reducing anxiety, depression and fatigue.

Keywords: Occupational health; worker health; pilatespilates and ergonomics

Many authors consider quality of life, as synonymous with health, and absence of disease ${ }^{1}$, and while by others as understand it as a more comprehensive concept, which comprises as social factors, well a health conditions, such as physical, mental, psychological and emotional ${ }^{2}$

The construction of a quality work environment for all employees becomes possible when the company offers diverse forms of quality of life at work to all its members in a comprehensive and objective manner. The biopsychosocial positioning represents the differential for a diagnosis, campaigns, service creation and implementation of projects aimed at the preservation and development of people, during work in the company ${ }^{3}$.

The health of the worker is inserted within a public health, and comprises a link between production, work and health. It starts from the principle that it is an action of work and an important part of the health-teaching process, bringing with it a reflection where the workers are the main protagonists in this context, contributing to a favorable work environment for the general staff ${ }^{4}$.

In particular, the working class of banks is undergoing profound changes over the years 5 . Such modifications are considered to have worsened working conditions, contributing to the dissatisfaction of the employee, without career development programs, becoming an empty, monotonous and repetitive activity ${ }^{6,7}$ 
Studies indicate ${ }^{8}$ that the implementation of activities that promote quality of life without work ${ }^{9}$, contribute positively to employees, increasing productivity and reducing workplace complaints.

As activities developed for improvement in the scope of work, the relationship is both human and professional among clients and co-workers ${ }^{10}$.

A quick massage or fast massage is also known ${ }^{11}$ it is a massotherapy technique, especially specialized in work, muscle tension and the presence of painful points in the muscles in order to relieve one of the main complaints of the worker ${ }^{12}$. It is an appreciative massage technique, as well as an anatomy and physiology of the human body ${ }^{13}$. It usually uses a specific chair to perform the massage, come the worker (patient), but which is comfortable and exposes the region of the neck, shoulders and upper and lower dorsum ${ }^{14,15}$.

The Pilates method was devised by the German Joseph Humbert Pilates (1880-1967) during the First World War, relying on principles of Eastern culture, such as yoga, martial arts and meditation. Pilates is set up by trying to control the muscles involved in movement in the most conscious way possible. The six basic principles of the method are: concentration, consciousness, control, "centering," breathing, and controlled harmonic motion ${ }^{16}$.

The Pilates method can be performed in two main ways, on using the apparatus and on the ground. Considerations about method, balance, body awareness, muscle relaxation, breathing control, stress and anxiety control, have been used with an important tool in the practice of work gymnastics in the areas of labor rights ${ }^{17,18}$.

The close relationship between quality of life, whether in personal life or quality of life at work, may depend directly on the subjects emotional state. Thus, we support the hypothesis that an environment free of stress factors can contribute to the well-being or better quality of life at work both in the personal aim, that is, by reducing or excluding the episodes of anxiety and depression we somatize a physical, mental and emotional balance as a whole.

In view of the above, the central objective of the study was to evaluate the efficacy of quick massage and solo pilates on the level of anxiety and depression of employee of a given a company in the municipality of Itajubá, state of Minas Gerais.

\section{METHODS}

\section{Type of Study, Location and Research Ethics}

This was a randomized, controlled and blinded study carried out between april and december 2017. It was developed in the physiotherapy department of the University Center of Itajubá (Fepi), together with a private banking institution, in the municipality of Itajubá, state of Minas Gerais. The project was sent to the Research Ethics Committee of the University Center of Itajubá and obtained a favorable opinion under number 1.045.371/ 2015.

\section{Composition and Characteristics of the Sample}

The study included initially 70 employees, who were registered according to the consolidation of labor laws (CLT) and outsourced employees were not included. The sample consisted of employees of both genders, regardless of age, height, weight, socioeconomic level, culture level, schooling level or working time at the banking institution.

The selection of the sample considered all the employees of the banking unit, but as described in table 1, the universal sample was 70 individuals; however, taking into consideration the inclusion criteria, only 50 met the eligible criteria.

All participants signed the informed consent form, which included detailed explanations of the project as well as all phases of the project. The researchers made a brief speech to facilitate their understanding of the project, in order to clarify all the doubts of

Table 1: Detail of the techniques of quick massage ${ }^{13-15}$

\begin{tabular}{llrc}
\hline Body Region & \multicolumn{1}{c}{ Technical } & Repetitions & Time \\
\hline Head & $\begin{array}{l}\text { Pressure with thumbs in several random lines on the head, circular or } \\
\text { transverse friction at various points on the head and straightening alternating } \\
\text { slow and rapid movements throughout the circumference of the head. }\end{array}$ & $5 \mathrm{x}$ minutes \\
Neck & $\begin{array}{l}\text { smoothing in the cranial-caudal and caudal-cranial direction with medium } \\
\text { pressure, slight kneading with light pressure in the same directions } \\
\text { mentioned above. }\end{array}$ & $5 x$ & 5 minutes \\
Shoulder & $\begin{array}{l}\text { upper-to-lower trapezius thumb, upper and lower trapezius rolling and } \\
\text { kneading, upper and lower trapezius lightweight straightening. }\end{array}$ & $5 \mathrm{x}$ & 5 minutes \\
Cervical Upper & $\begin{array}{l}\text { skull-caudal and cranial-to-cranial smoothing with light pressure, rolling in } \\
\text { the same direction, kneading in the same direction. }\end{array}$ & $5 \mathrm{5x}$ & 5 minutes \\
\hline
\end{tabular}


employee wishing to participate in the project, also, the risks and benefits were explained with figures and posters for better understanding.

The groups of the present study were divided as follows: quick massage group (QMG $n=20)$, pilates group ( $P G n=20)$ and control group with verbal orientations and leaflets explaining posture and quality of life at work (CG $n=10)$ figure 1.

\section{Inclusion Criteria}

Not being subjected to any drug therapy, being a registrar of the bank agency, having the commitment to participate in all phases of the study and signing and delivering the free and informed consent form.

\section{Exclusion Criteria}

Bank employee who is the in medical treatment, such as: spine, depression, anxiety, emotional problems, outsourced employees, employees who did not participate in all phases of the study, employees who did not sign and deliver the free and informed consent form.

\section{Randomization}

Participants eligible for study participation were randomized according to the formation of the experimental groups, that is, a randomized allocation was made.

\section{Evaluation Tools}

The instruments used in this study are intended to measure the direct effects that the techniques (quick massage, pilates and verbal orientations) will impact on the health of the banking sector worker.

\section{Hospital Anxiety and Scale Evaluation Depression (HAD) ${ }^{19}$}

The instrument contains 14 questions, with 4 possible answers. Each answer equals 1 point in the scoring scale. The questions related to a possible picture of anxiety are: 1, 3, 5,7, 9, 11 and 13 and the questions related to a possible depressive picture are: 2, 4, 6, 8, 10, 12 and 14 respectively. The evaluation of the obtained points was done as follows: 0-7 points (unlikely), 8-11 points (possible) and $12-21$ points (probable) ${ }^{19}$

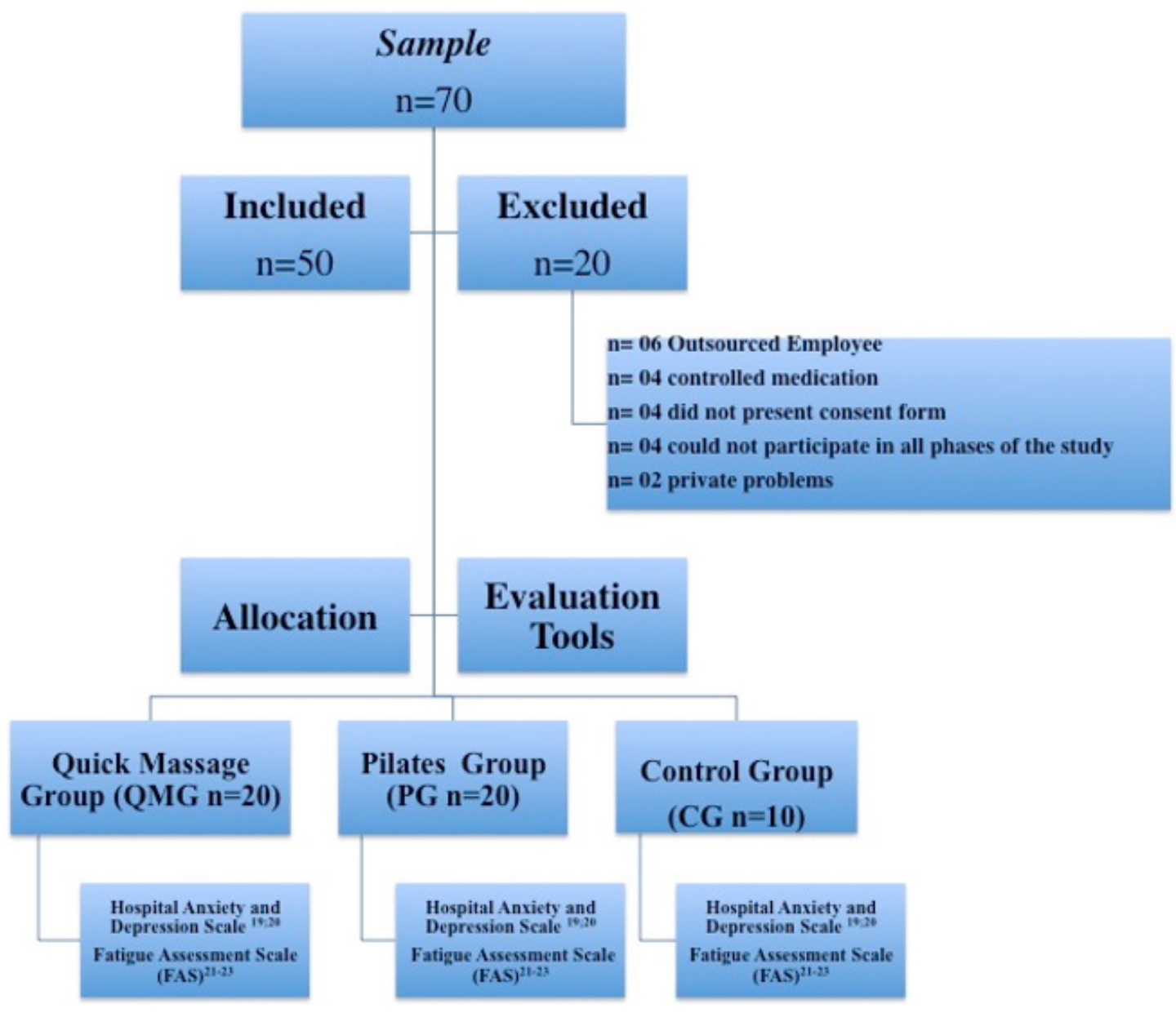

Figure 1: Universal Sample. 


\section{Fatigue Assessment Scale (FAS) ${ }^{20-22}$}

It is an instrument for evaluation at the level of fatigue ${ }^{22}$. whose main purpose is to evaluate the individual's experiencing of the symptoms of fadigue. This instrument evaluates the responses taking into account a scoring scale ranging from 1 to 5 , with high scores meaning a high level of fatigue, and low scores meaning a low rate of fatigue ${ }^{20-22}$.

\section{Application of Intervention Protocols}

The evaluation and intervention procedures were applied in 3 different moments during the nine-month follow-up. An evaluation was performed at the beginning of the protocol (April), after 4 months (August), and finally, the last evaluation was conducted 4 months (December) (Figure 2)

\section{Intervention Protocols}

\section{Protocol pilates}

\section{Protocol quick massage}

The protocol using pilates exercises was performed using 4 exercises that requested contribution of all body structure:

The choice of pilates technique exercises took into account the experience of one of the authors of the study, who presents complete training in mat pilates and reformer pilates. Therefore, the careful selection of which techniques-exercises would be included in the program took into account the hypotheses of the study, which reported that the subjects participants could present anxiety and depression, thus selecting techniques-exercises that could promote a reply to those tables mentioned above. In the current literature, no reliable study was found that related the type of pilates technique-exercise with occupational stress, which makes the present study a pioneer in this intervention.

\section{Verbal guidance protocol - control group}

The control group received only verbal guidelines on ergonomic care, postural guidelines, guidelines on mantle health and emotional balance. Guidelines were given 3 times a week, averaging 30 minutes.

\section{Data Analysis}

The data collected were initially submitted to descriptive statistical analysis, with frequency tables for categorical variables and measures of position and dispersion for continuous variables. The data were entered into the statistical software PrismGrapPad where the analysis of variance (ANOVA) and the multiple comparison between columns (Turkey's) were calculated. The results were presented in tables and graph.

\section{RESULTS}

The means and standard deviation of all groups was One-way analysis of variance, obtaining value of $<0.0198$, being considered significant. It is observed in the table 2 that the comparisons between the group that received the quick massage protocol and the group that received the pilates protocol did not present statistical difference, when they were evaluated with 3,6 and 9 months for with the HAD

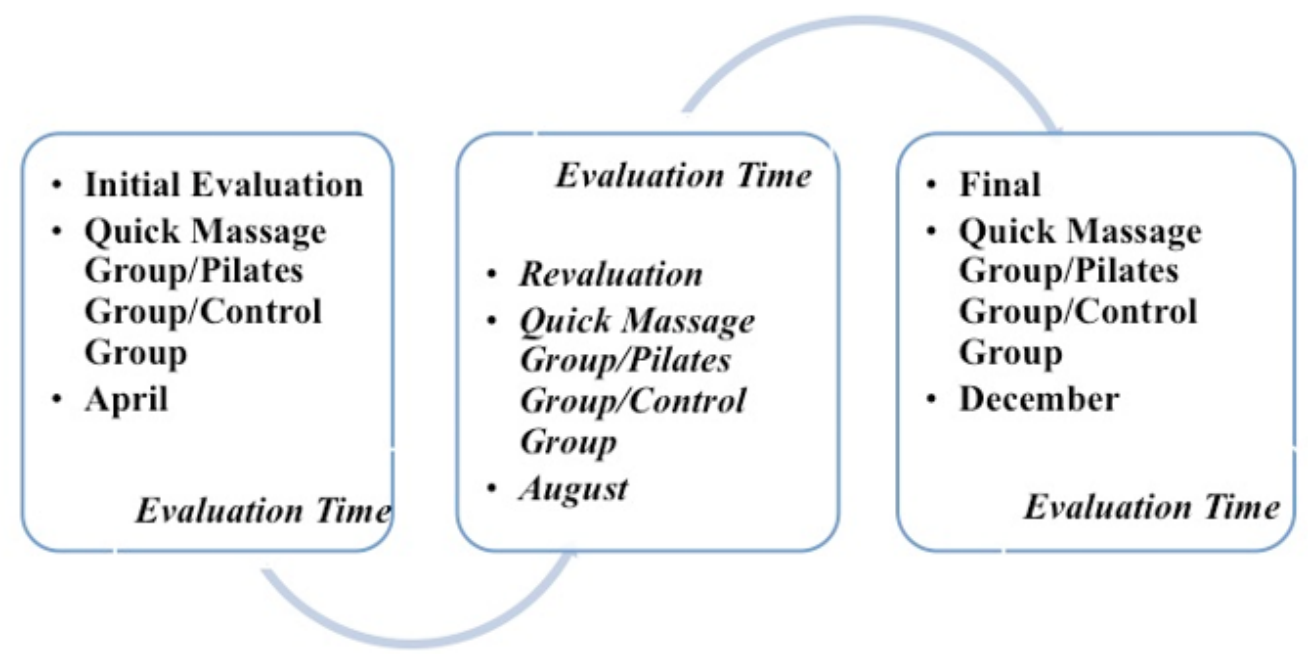

Figure 2: Schedule of evaluation and application of protocol.

Note: The figure above represents the evolutionary framework of the evaluation months experimental groups studied in the 9-month period. In April, the instruments of evaluation and application of the quick massage (QMG) and pilates (GP) protocols were applied in the respective groups. The verbal guidance group received only guidelines. The same routines were applied in the month of July and were repeated in December. 
Table 2: Pilates' techniques detailing.

\begin{tabular}{|c|c|c|c|}
\hline Exercise & Characteristics & Repetitions & Time \\
\hline One Leg Circle & $\begin{array}{l}\text { Positioned in dorsal decubitus, should maintain a slight external } \\
\text { rotation of the hip, the upper limbs should be parallel along the } \\
\text { body, contracted abdomen, inhale and at the expiration start the } \\
\text { circumference of the right hip, which will be at } 90^{\circ} \text {, will flex, abduct } \\
\text { and extend the leg. After finishing the movement, the same should } \\
\text { be done with the other leg. This exercise aims to strengthen the hip } \\
\text { flexor and thoracic and lumbar spine, assist in hip mobility, promote } \\
\text { hip stretching and knee flexors. }\end{array}$ & $5 x$ & 5 minutes \\
\hline Shoulder Bridge & $\begin{array}{l}\text { Positioned in dorsal decubitus, with feet resting on the floor, with hip } \\
\text { in abduction, knee in flexion, upper limbs parallel to the body and } \\
\text { abdomen in isometric contraction. Begin with inspiration and when } \\
\text { exhaling to do hip flexion unilateral and extend the leg on the same } \\
\text { side. Perform the movement on the opposite side. This exercise aims } \\
\text { to strengthen the extensors of the hip and abdomen, contributes to } \\
\text { the movements of the spine and control of the pelvic girdle. }\end{array}$ & $5 x$ & 5 minutes \\
\hline Swan Dive & $\begin{array}{l}\text { Positioned in the ventral decubitus, with the limbs parallel to the side } \\
\text { of the body, maintaining the upper limbs in adduction and elbows in } \\
\text { flexion. Perform inspiration associated with spinal hyperextension } \\
\text { associated with elbow extension by gradually raising the trunk. } \\
\text { This exercise has the power to strengthen the spinal muscles, with } \\
\text { emphasis on the muscles of the lumbar spine, extensors of the hip } \\
\text { and abdomen, and the pelvic girdle. }\end{array}$ & $5 x$ & 5 minutes \\
\hline Neck Pull & $\begin{array}{l}\text { Positioning in dorsal decubitus, column in neutral position, hands } \\
\text { should be behind the neck, contraction of the abdomen should occur } \\
\text { at all stages of exercise. After the inspiration, perform the exhalation } \\
\text { and flex the spine from the cervical flexing the spine until you can } \\
\text { stay in the sitting position and with hip flexion. After reaching the } \\
\text { seated position, the patient should repeat the reverse movement until } \\
\text { he or she is in the dorsal decubitus position again. This exercise aims } \\
\text { to strengthen the abdomen, increase the mobility of the spine, and } \\
\text { promote stretching of the back of the body. }\end{array}$ & $5 x$ & 5 minutes \\
\hline The Teaser & $\begin{array}{l}\text { Positioning in dorsal decubitus, with } 90^{\circ} \text { hip flexion, foot towards the } \\
\text { ceiling, knees in extension, it is important to perform the isometric } \\
\text { contraction of the abdomen. The continuation of the exercise is } \\
\text { raising the upper limbs by flexing the shoulder, bringing them behind } \\
\text { the head, keeping the back on the floor. The purpose of this exercise } \\
\text { is to strengthen the abdomen and lower limbs, promote control of } \\
\text { the shoulder girdle, and in the mobilization of the spine and postural } \\
\text { control. }\end{array}$ & $5 x$ & 5 minutes \\
\hline
\end{tabular}

and FAS instruments. However, it is noted that when presenting the detailed data of each group (mean and standard deviation) it is observed that the group that received the quick massage has a small advantage as follows: quick massage group ( 3 months) $6.51 \pm 3.37$, (6 months) $4.03 \pm 0.82$, (12 months) $3.43 \pm 1.15$. Pilates group ( 3 months) $6.21 \pm 1.98016$, (6 months) $4.26 \pm 0.57873$ (9 months) $4.14 \pm 0.63$.

It can be observed in figure 3 that the control group, which received only verbal orientations, (3, 6 and 9 months) presented reduction of the levels of fatigue, anxiety and depression, but it was not significant. However, when we compared quick massage with verbal guidance and pilates with verbal guidance we observed significance.

These results corroborate the initial idea of the authors of the study, which, supported by recent studies, observed a significant improvement in the quality of life of employees in diverse branches when they received some treatment or technique for their quality of work life. Both quick massage and pilates promoted important reductions in the evaluation of HAD and FAS instruments, suggesting that such procedures could be included in the procedures applied to the quality of life at work, especially the banking ones. 


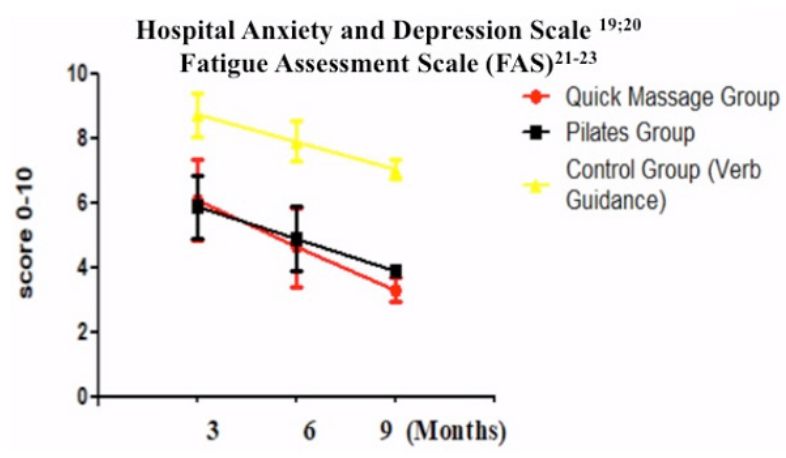

Figure 3: assessment of avaluation instruments versus experimental groups.

\section{DISCUSSION}

Occupational stress understood as stress at work represents an important risk to physical and emotional well-being and has been the reason for several studies in different sectors, especially the securities agencies ${ }^{23-28}$

An initial assessment was used to measure anxiety, depression and fatigue index, using the evaluation tools: Hospital anxiety and mild depression scale $(H A D)^{19,29}$ and fatigue assessment scale (FAS) ${ }^{20-22}$. An evaluation was carried out at 3 months, 6 months and at 9 months, as well as possible to measure in detail the impact of the interventions proposed in the not case, quick massage is pilates.

Another study involving bank network workers ${ }^{30}$ analyzed the prevalence of stress as well as the main sources of this stress in the work environment. It was a cross-sectional study, carried out in 2004, including state and private banks ${ }^{30}$ Among the events most reported as stressors in the activity and organizational environment of the bank, we can highlight: pressure by the manager, pressure to by goals, $(65 \%)$ responsibility for loss of values $(58 \%)$, customer pressure $(45 \%)$, customer satisfaction (47\%), risk of assaults (44\%). In the evaluation of stress, it was verified that $47 \%$ of the sample had some typical symptomatology of stress. When examined separately, $15 \%$ were obtained in the alert phase, $46 \%$ in the resistance phase and $18 \%$ in the exhaustion phase ${ }^{30}$.
In the present study, the causes of individual anxiety, depression and fatigue episodes it was not analyzed what, but rather the general situation of the employee who thought he was experiencing symptoms of anxiety, depression or fatigue. The applied instruments present an important and specific reliability to measure these variables. It was observed that quick massage and pilates decreased anxiety, depression and fatigue rates after the 3 evaluations according to the experimental times. The results are as follows: quick massage group (3 months) $6.51 \pm 3.37$, (6 months) $4.03 \pm 0.82$, (12 months) $3.43 \pm 1.15$ and the pilates group (3 months) $6.21 \pm 1.98016$, (6 months) $4.26 \pm 0.57873$ (9 months) $4.14 \pm 0.63$.

Another study analyzed through a systematic review including articles related to the subjects: banking, employee, depression, and anxiety. This study examined in the last 10 years the main causes that bank employees reported as being a potentiating agents of stress, fatigue and depression in the last 10 years by banking employee. Among the factors that stand stood out are: psychological harassment, feelings of loss of personal identity, physical illnesses, such as repetitive strain injuries, discrimination and suffering, anxiety, physical and mental fatigue, depression, fear, various phobias, insomnia and even suicide ${ }^{31}$.

In the present study, the protocols used were based on choice, ease of execution, zero cost, practicality, and speed and effectiveness of the results. Faced with this, the detailed choice of each gesture of the quick massage and each pilates exercise, was based upon the complaints of the bank employees. Thus, each massage technique and each exercise of pilates sought to promote physical, psychic and social wellness, as well as to directly contribute for the improvement of work productivity, interpersonal relationship and even promote important body changes, such as increased flexibility and decrease of tension throughout the body.

\section{Conflicts of Interest}

The authors declare no conflicts of interest.

\section{REFERENCES}

1. Fleck MPA, Louzada S, Xavier M, Chachamovich E, Vieira G, Santos L, et al. Aplicação da versão em português do instrumento de avaliação de qualidade de vida da Organização Mundial da Saúde (WHOQOL-100). Rev
Saude Publica. 1999;33(2):198205. http://dx.doi.org/10.1590/ S0034-89101999000200012. PMid:10413938.

2. Pereira ÉF, Teixeira CS, Santos A. Qualidade de vida: abordagens, conceitos e avaliação. Rev Bras
Educ Fís Esporte. 2012;26(2):24150. http://dx.doi.org/10.1590/S180755092012000200007.

3. Gonçalves A, Gutierrez GL, Vilarta R, organizadores. Gestão da qualidade de vida na empresa. Campinas: IPES Editorial; 2005. p.189. 
4. Mendes R, Dias EC. Da medicina do trabalho à saúde do trabalhador. Rev. Saúde Pública. 1991;25(5):341-9. http://dx.doi.org/10.1590/S003489101991000500003.

5. Merlo AR, Barbarini N. Reestruturação produtiva no setor bancário brasileiro e sofrimento dos caixas executivos: um estudo de caso. Psicol Soc. 2002;14(1):103-22. http://dx.doi.org/10.1590/S010271822002000100007.

6. Codo W, Sampaio JJC. Síndrome do trabalho vazio entre bancários. J. bras. psiquiatr. 1992;42:23-28.

7. Falqueto MGFB. Construção social da identidade bancária: o que é ser bancário? In: Simpósio de Saúde Mental e Trabalho Bancário; 1992; Vitória, Espírito Santo. Universidade Federal do Espírito Santo, 1997.

8. Nadler DA, Lawler EE 3RD. Quality of work life: perspectives and directions. Organ Dyn. 1983;11(3):2030. http://dx.doi.org/10.1016/00902616(83)90003-7.

9. Moulin, MGB. Trabalho, gênero e saúde mental: modos de inserção da mulher no trabalho bancário [dissertation]. Rio de Janeiro: Universidade Federal do Rio de Janeiro; 1996.

10. Assunção, AA. A saúde bancária na era moderna: fatores de risco - saúde no trabalho bancário. São Paulo: Central Única dos Trabalhadores; 1993.

11. Cassar MP. Manual de massagem terapêutica: um guia completo de massoterapia para o estudante e para o terapeuta. São Paulo: Manole; 2001.

12. Domenico G, Wood EC. Técnicas de Massagem de Beard. 4. ed. São Paulo: Editora Manole; 1998.

13. Moretti A, Lima V. Massagem no Ambiente do Trabalho. 1. ed. São Paulo: Phorte; 2010.

14. Rogel CSP, Resi AL, Oliveira MG. Quick Massage no centro de saúde: uma proposta de cuidado e promoção de saúde para profissionais da atenção primária. In: Anais do $12^{\circ}$ Congresso Brasileiro de Medicina de Família e Comunidade; 2013 Maio 29Jun 2; Belo Horizonte; 2013. p. 19-22.
15. Silva, S.T; Dutra, C.M.R. 2013. Quick Massage e os seus benefícios relacionados ao ambiente de trabalho. Curitiba: Universidade Tuiuti do Paraná. 9p.

16. Sacco ICN, Andrade MS, Souza PS, Nisiyama M, Cantuária AL, Maeda FYI, et al. Método Pilates em revista: aspectos biomecânicoa de movimentos específicos para reestruturação postural: estudos de caso. R. bras. Ci e Mov. 2005;13(4):65-78.

17. Miranda LB, Morais PDC. Efeitos do método Pilates sobre a composição corporal e flexibilidade. RBPFEX. 2012;3(13):16-21.

18. Mares G, Oliveira KB, Piazza MC, Preis C, Neto LB. A importância da estabilização central no método Pilates: uma revisão sistemática. Fisioter Mov. 2012;25(2):445-51. http://dx.doi.org/10.1590/S010351502012000200022.

19. Zigmond, AS, Snaith, RP. The hospital anxiety and depression scale. Acta Psychiatr Scand. 1983;67:361-70. http://dx.doi. org/10.1111/j.1600-0447.1983. tb09716.x. PMid:6880820.

20. Drent M, Lower EE, De Vries J. Sarcoidosis-associated fatigue. Eur Respir J. 2012;40(1):255-63. http://dx.doi. org/10.1183/09031936.00002512. PMid:22441750.

21. Kleijn WPE, De Vries J, Wijnen PAHM, Drent M. Minimal (clinically) important differences for the Fatigue Assessment Scale in sarcoidosis. Respir Med. 2011;105(9):138895. http://dx.doi.org/10.1016/j. rmed.2011.05.004. PMid:21700440.

22. De Vries J, Michielsen H, Van Heck $\mathrm{GL}$, Drent M. Measuring fatigue in sarcoidosis: the Fatigue Assessment Scale (FAS). Br J Health Psychol. 2004;9(Pt 3):279-91. http://dx.doi. org/10.1348/1359107041557048. PMid:15296678.

23. Seifert AM, Messing K, Dumais L. Star wars and strategic defense initiatives: work activity and healty symptoms of unionized bank tellers during work reorganization. Int J Health Serv.
1997;27(3):455-477. http://dx.doi. org/10.2190/7KUK-2D4L-0G1N-8DNY. PMid:9285277.

24. Sousa FM, Messing K, Menezes $\mathrm{PR}, \mathrm{Cho} \mathrm{HJ}$. Chronic fatigue among bank workers in Brazil. Occupation Medicine (Lond). 2002;52(4):18794.

25. Palacios M, Duarte F, Camara VM. Trabalho e sofrimento psíquico de caixas de agências bancárias na cidade do Rio de Janeiro. Cad Saude Publica. 2002;18(3):843851. http://dx.doi.org/10.1590/ S0102-311X2002000300028. PMid:12048610.

26. Donato YB, Almeida EM, Diniz EM, et al. Caracterização dos níveis de stress em bancários da cidade de João Pessoa, PB. In: Anais I Congresso Norte Nordeste de Psicologia. V Semana Baiana de Psicologia. Salvador. Bahia; 1999. [citado 2018 Fev 12]. Disponível em: http://www.ufba.br/conpsi/conpsi1999/ paineis.

27. Nunes NA, Molina FB, Zola TRP, Lauris JRP, Nunes OBC. Avaliação do nível de estresse emocional em bancários de Cafelândia/SP e percepção de sintomas bucais. Rev. Fac. Odontol. Lins. 2005;17(1):2332.

28. Sousa FM, Messing K, Menezes PR, Cho HJ. Chronic fatigue among bank workers in Brazil. Occupation Medicine (Lond). 2002;52(4):18794.

29. Botega NJ, Bio MR, Zomignani MA, Garcia JRC JR, Pereira WAB. Transtornos do humor em enfermaria de clínica médica e validação de escala de medida (HAD) de ansiedade e depressão. Rev Saude Publica. 1995;29(5):35563. http://dx.doi.org/10.1590/ S0034-89101995000500004. PMid:8731275.

30. Koltermann ITAP, et al. Estresse ocupacional em trabalhadores bancários: prevalência e fatores associados. Saúde. Ahead of Print. 2011;37(2):3348.

31. Marques GS, Giongo CR. Bank workers in distress: A national literature analysis. Rev. Psicol., Organ. Trab. 2016;16:220-235. 